\title{
TANGGA NADA HIBRID MELALUI KONSEP PENCIPTAAN MUSIK
}

\author{
Berehme Adyatmo Purba ${ }^{1}$ \\ Program Pascasarjana Institut Seni Indonesia Yogyakarta
}

\begin{abstract}
This writing is in the background of the phenomenon of existing phenomena of some composers making works of musical composition. Dominate the idea of story-based musical creation (ektramusikal) in the academic environment, resulting in an imbalance of explanations of the work. The purpose of the author is to create a concept of formation of hybrid tone, to participate as part of a musical discussion such as conceptualization before the embodiment of the work. Then to know that the many background ideas of the creation problem from the intramusical aspect of the creation dominance of the extramusical element. Combining elements of music from two different types of classification ladder. The process of making these hybrid tones is the result of developing the concept of a pre-existing hybrid scale, beginning with an experiment of tone interval combinations. Hybridity-related because it uses two elements of music combined, to underlie the exposure of concepts such as systematic flow of two elements of music mixed from two musical cultures. So with this intention as a trigger for writers and composers who want to do concept development also strengthen the intramusikal argument in the creation that is done, thus enriching the discourse in the field of musical composition.
\end{abstract}

Keywords: Scale, Hybrid, Creative Idea

\begin{abstract}
Abstrak
Tulisan ini di latarbelakangi fenomena-fenomena gejala yang ada dari beberapa komponis membuat karya komposisi musik. Mendominasinya ide penciptaan musik berlandaskan cerita (ektramusikal) di lingkungan akademik, sehingga adanya ketidakseimbangan penjelasan kekaryaan. Adapun tujuan penulisyaitu membuat suatu konsep pembentukan tangga nada hibrid, untuk turut berperan sebagai sebagian pembahasan musikologi seperti pembuatan konsep sebelum adanya perwujudan karya. Kemudian untuk mengetahui bahwa banyaknya ide latar belakang permasalahan penciptaan dari aspek intramusikal dari dominasi penciptaan dari unsur ekstramusikal.Menggabungkan unsur musik dari dua jenis

\footnotetext{
1 Mahasiswa S-2 Penciptaan Program Pascasarana Institut Seni Indonesia Yogyakarta Email: dmopurba@yahoo.com
} 
tangga nada yang klasifikasinya berbeda. Proses pembuatan tangga nada hibrid ini merupakan dari hasil pengembangankonsep tangga nada hibrid yang telah ada sebelumnya, di awali suatu eksperimen kombinasikombinasi interval nada. Terkait hibriditas karena menggunakan dua elemen musik yang dipadukan, untuk melandasi pemaparan konsep seperti sistematika alur perpaduan dua elemen musik yang diambil dari dua kultur musik. Maka dengan maksud ini sebagai suatu pemicu agar penulis maupun komponis yang ingin melakukan pengembangan konsepturut memperkuat argumenintramusikal dalam penciptaan yang dilakukan, sehingga memperkaya wacana dalam bidang komposisi musik.

Kata kunci: Tangga Nada, Hibrid, Ide Penciptaan

\section{Pendahuluan}

Pembuatan karya pada dasarnya tentu memiliki aspek kebaruan yang tidak lepas dari pengalaman empiris komponis seperti lingkungan saat ini. Dalam penciptaan musik terdapat proses berkarya dengan melihat kekinian komponis yang direalisasikan untuk adanya suatu kebaruan. Munculnya materi-materi baru dimulai dari berbagai temuan ataupun pengembangan teori dan praktis yang kerap sekali dilakukan untuk mengupdate penciptaan karya yang dilakukan. Kebaruan itu tidak lepas dari kreativitas pencipta yang dihasilkan dari berbagai pengalaman atau kegelisahan yang ingin diungkapkan melalui suatu bentuk konkrit.

Gotz (Deliege \& Wiggins, 2006) mengidentifikasi kreativitas secara langsung dengan menyatakan bahwa "kreativitas merupakan proses atau aktifitas merealisasikan wawasan dengan bebas". Apa yang biasa kita pikirkan sebagai "proses kreatif" terdiri dari beberapa wilayah, di mana hanya satu yang muncul di antara ide dan hasil produk yang dapat dicirikan sebagai "kreatif". Kreativitas dalam sudut pandangan ini didefinisikan secara keseluruhan tanpa pertimbangan lain yang menyangkut gagasan orisinalitas atau nilai. Ketika berbicara mengenai tingkat kreativitas yang ditunjukan seseorang dalam produksi karya maupun ide, seolah mengacu pada luasnya perbedaan basis dari pengalaman dan pengetahuan seseorang yang telah ada sebelumnya.

Beberapa tahun terakhir,kreativitaspenciptaan karya musik masih banyak mengangkat persoalan karya berdasarkan cerita atau membuat komposisi musik programa, khususnya dalam ranah akademis di Indonesia. Dominasi ini sulit untuk diukur karna pembahasan akan lebih kepada permasalahan seperti dari daun jatuh dari pohon, delapan arah mata angin. Selain itu terdapat juga beberapa komponis muda dalam suatu 
pertunjukan, yang menampilkan karya-karya komposisi dalam festival musik tembi. Sinopsis sebagai pamandu untuk menjelaskan karya yang menjadi suatu tafsiran subjektif agar dapat masukdalam imajinasi terhadap karya (Admin, 2016).

Pertanggungjawabannya sangat umum didominasi oleh deskripsi analogi atau ceritanya. Gaya musik, struktur musik tertentu, unsur musik (pitch, harmoni, durasi, intensitas, dan warna bunyi) sering kali berupa konsep-konsep yang umum dan elementer saja. Keterjebakan unsur ekstramusikal pada musik programa cenderung menjadi fokus utama komponis dalam penciptaan karya. Hal ini sering dianggap lumrah, padahal unsur ekstramusikal merupakan satu dari sekian banyak dalam sebuah sistem komposisi (Koapaha, 2016).

Sebuah refleksi unsur sejarah dari fenomena-fenomena dilalui beberapa komponisdalam pendidikan musik, seperti komponis Indonesia yang telah melahirkan ruang musik dalam perkembangan pembangunan kreativitas kesenian maupun kebudayaan di Indonesia. Amir Pasaribu lahir tahun 1915adalah salah seorang komponis Indonesia yang belajar musik di Belanda, lebih dikenal sebagai salah seorang komponis dengan karya-karya komposisi musik instrumental. Ada beberapa karya tulisan yang membahas tentang permasalahan tentang musik, lebih spesifik buku tersebut sebuah kumpulan esai kritik musik.

Amir Pasaribu juga membuat beberapa karya musik dengan dasar musik barat. Misalnya karya "Sriwijaya Variations"yang menggunakan penggabugan materi musik seperti adanya kombinasi sistem nada antara whole tone (barat) dan pelog-slendro (timur), dan modus-modus lainnya juga di beberapa bagian. Penciptaan karya ini tidak berdasarkan suatu proses penelitian dengan sebuah permasalahan umum yang menggunakan metode tertentu atau lebih fokus kepada produksi produk kekaryaan, sehingga sulit mencari objektifitas secara umum apa yang menjadi gejala dalam penciptaan karya (Lana, 2012).

Komponis Indonesia seperti Slamet Abdul Syukur yang studi musik di Paris dengan Messiaen dan Dutillux. Disamping itu terkenal sebagai penulis dan budayawan dan juga dikenal membuat sebuah konsep baru dengan judul "Musik Minimax". Pada umumnya musik Slamet selalu bersifat "minimalis", istilah ini kelihatan sangat tepat dengan estetikanya. Minimax, suatu pilihan lain yang berangkat dari keterbatasan (minim) memanfaatkannya secara maksimal namun musiknya bukanlah minimalis dalam arti aliran Musik Minimalis. Konsep ini sangat kondusif untuk mengembangkan 
kreativitas serta sensifitas orang awam, terutama dalam rangka pendidikan musik (Mark, 2014).

Selain itu, ada jugakomponis-komponis Indonesia seperti W.R Supratman, Kusbini, Ismail Marzuki, dan Cornel Simanjuntak. Lagu seriosa yang diciptakan para komponis mempunyai peranan yang besar terhadap perjuangan mencapai kemerdekaan. Pada waktu ikut berjuang melawan penjajah dengan cara melalui lagu-lagu perjuangan yang mereka ciptakan. Banyak sekali pesan terselubung dalam syair-syair lagu perjuangan, cinta kepada tanah air dan keinginan untuk menjadi bangsa yang merdeka yang terlepas dari penjajahan. Lagu penjajahan disebut sebagai musik nasional yaitu musik yang diciptakan untuk tujuan nasional untuk dapat mempersatukan bangsa dan tidak terdapat unsur etnis kedaerahan (Yunita, 2012).

Jika menyoroti proses penciptaan karya dalam tradisi musik barat seperti Debussy pada saat berada di sebuah transisi zaman akhir romantik dengan zaman modern sekitar tahun 1850-1900, yang mana konten musik yang sangat didominasi Jerman saat itu. Debussy seorang komponis Perancis, tokoh yang paling menonjol dengan gaya sastra Prancis terkait dengan musik impresionis disamping Maurice Ravel. Pada salah satu karyanya berjudul "Pagodes" terdapat sebuah latar belakang dari fenomena impresi terhadap Gamelan Jawa dalam pameran dunia paris tahun 1887 di Paris(Mark, 2003).

Selain itu Debussy juga banyak mengadopsi idiom-idiom dari luar Eropa barat, karena pada masa romantik musik sudah habis di eksploiter, kemana lagi mencari. Maka kemudian Debussy mencari jalan keluar untuk mencari materi baru seperti musik tradisi di Eropa timur, timur tengah, gamelan jawa. Untuk menimbulkan suatu sikap yang tidak lagi romantik, hanya semata-mata untuk memunculkan 'kesan' ditarik dari luar romantik namun tetap dengan Mannerism romantik (Hardjana, 2010). Hingga munculnya sebuah gaya musik Impresionisme pada zaman itu yang di adopsi dari istilah Seni Rupa. Musik impresionis menurut Sumaryo (1978), penggunaan timbre (warna) dapat dicapai melalui instrumentasi, penggunaan harmoni dengan gerakan paralel, tekstur, kombinasi akor baru, atau unsur ekstramusikal dalam musik programa.

Kemudian yang paling berpengaruh dalam musik eropa yang dianggap kontroversi melawan tradisi aturan-aturan lama musik eropa barat yang telah lama ada. Karena batas wilayah tonalitas yang telah ada berabad-abad di putus. Arnold Schoenberg 1874-1951 lahir dalam keluarga Yahudi di Wina. Tahun 1925 diangkat menjadi Profesor di Akademi Seni Musik, di Berlin. Tahun 1934 ia tinggal di Amerika Serikat tempat diangkat Profesor di sekolah musik Malkin, Boston. Metode duabelas nada merupakan 
suatu prosedur praktis yang di pelopori Schoenberg, yaitu suatu prosedur dasar tentang pengaturan duabelas nada selurunya dengan memberi "kebebasan" dan memberi peran pada perlakuan individual atas melodi, ritme, dan harmoni. Schoenberg yang menolak aturan pengomposisian yang telah dipakai tiga abad, yaitu konsonan dan tonal, serta sistem harmoni dan melodi tradisional yang telah menjadi "second nature" (dunia konvensi) bagi para komponis. Dan akan menyadarkan bahwa tak ada batasan, aturanaturan tradisional dalam penyusunan komposisi (Budiarto, 2001).

Teknik Schoenberg itu semata-mata merupakan pengorganisasian materi musik untuk menjamin kesamaan setiap nada dalam duabelas nada itu, yaitu metode pengorganisasian musik atonal secara lebih sistematis. Namun bukan suatu prosedur yang otomatis dalam menyusun komposisi yang semata-mata hanya memanipulasi nada-nada, namun suatu ekspresi dari pengalaman estetis. Kalau Debussy dikenal sebagai tokoh musik impresionis, maka Schoenberg dengan gaya musik yang menghindari bentukbentuk keindahan tradisional dan sebagai kebebasan distorsi bentuk dan warna untuk melahirkan emosi ataupun sensasi yaitu ekspresionis.

Dari pemaparan beberapa contoh komponis diatas bahwasanya penciptaan musik itu melalui gejala permasalahan umum dan sebuah konsep musik baru, sehingga jelas objek materi yang digunakan bukan lagi berdasarkan permasalahan suatu cerita yang ingin diungkap lagi atau di representasikandengan analogi 'bahasa' musik. Selayaknya dalam proses penciptaan juga dapat melalui berbagai respon terhadap fenomena kekinian karena berpeluang menghasilkan kebaruan dalam karya dan konsep.

Maka dari beberapa argumen tersebut yang mendasari pembahasan ini akan melibatkan konsep musik dengan fokus terhadap pembahasan intramusikal. Yakni seperti menambah pembahasan yang berorientasi pada pembahasan wilayah teori intramusikal khususnya komposisi.Sebagai pertimbangan aspek musikalnya, bahwa tangganada merupakan unsur musik yang sangat mendasar. Dalam tulisan ini memiliki maksud untuk menawarkan sebuah konsep, yaitu menggabungkan komponen musik dari dua jenis tangga nada yang klasifikasinya berbeda dikonstruksi menjadi satu. Sehingga terjadi adanya proses hibrid dari penggunaan konsep pembentukan tangga nada. Suatu gagasan untuk membuat sebagian konsep komposisi terlebih dahulu untuk dijadikan sebagai bahan dalam pembuatan karya.

Pada tahap selanjutnya dalam hal ini akan lebih membahas mengenai apa dan bagaimana cara dalam mengimplementasikan dari rumusan konsep penciptaan yang ada. Merujuk pada apa yang telah umum digunakan sebagai metode penciptaan seni maka 
dalam tulisan ini juga akan menggunakan metode yang meliputi: Eksplorasi, Improvisasi/Eksperimentasi, dan Pembentukan. Proses kreatif ini menyesuaikan dengan objek materi yang di kembangkan, penjelasan tahapannya.

\section{Hibrida dalam Musik}

Ketika mendengar kata hibrid, hibriditas cenderung akan berasumsikan dekat dengan pelajaran dalam studi ilmu biologi atau kimia dan ilmu pengetahuan alam lainnya. Ini terbukti jika dalam pertanyaan-pertanyaan mengenai kata ini umumnya berpendapat adanya penggabungan dari suatu zat ke zat lainnya sehingga terbentuk sebuah zat baru. Namun jika berbicara dalam konteks saat ini terkhusus seni banyak menggunakan istilahistilah dari luar seni untuk dijadikan sebagai judul topik untuk ide penciptaannya.

Hibriditas menurutBhaba (2007)adalah sebuah proses penciptaan identitas kultural menjadijelas. Hibriditas lebih mengarah kepada perubahan identitas yang berujung pada perubahan subjektif. Maksud Bhaba dalam ranah ini adalah penggambaran atas bergabungnya dua bentuk budaya yang memunculkan sifat-sifattertentu dari tiap bentuknya, dan menjadi sifat yang dimiliki keduanya.

Dalam pandangan musikologi, hibriditas difokuskan pada seniman yang menghasilkan musik lintas genre dan media yang span instalasi, seni rupa, musik, teknologi, dan kinerja. Dengan itu jika dipandang dari sisi ilmu tentang kebudayaan maka kerap adanya yang dimaksud dengan hibridasi, inkulturasi, akulturasi. Itu dianggap sebagai suatu istilah perubahan budaya (cultural change). Maka dalam pembahasan ini akan diarahkan pada suatu bentuk hibridasi atau percampuran dari dua aspek yang disatukan sehingga wujudnya menjadi sesuatu yang baru. Dasar ini menjadi suatu konsentrasi dimana bentuk pengetahuan dan konkritnya (Mark, 2014).

Dalam perspektif etnomusikologi terminologi yang dipakai untuk menjelaskan fenomena yang sama (mengawinkan, menyatukan, menyampur), khususnya penyampuran elemen-elemen budaya musik yang terjadi melalui kontak budaya. Hibridisasi pada dasarnya menjadi sifat yang inheren (melekat) di dalam proses penciptaan musik, yaitu pengadopsian dan pencampuran elemen-elemen musikal dari sumber-sumber yang memiliki gaya berbeda atau yang baru. Pada masa lalu musik hibrida ini biasanya tumbuh dan berkembang di tengah-tengah masyarakat yang hidup di perbatasan dua kebudayaan berbeda tetapi mempunyai akar yang sama. Contoh yang sangat ideal dari bentuk-bentuk 
musik hibrida ini adalah tradisi permainan rebana Banyuwangi yang disebut Kuntulan, atau permainan Angklung Paglak yang ditampilkan dalam festival terkait ritus pangan di daerah itu. Di perbatasan dua kebudayaan ini bahasa, ritual dan pola kebudayaan masyarakatnya bercampur dan menghasilkan bentuk budaya baru yang berbeda (Siagian, 2013).

Ditengah-tengah dominasi industri musik global, beragam genre musik baru yang munculdilatari proses ini. Josep Marti (Siagian, 2013) melalui artikelnya tentang hibridisasi berpandanganbahwa hakekat nilai-nilai musik sesungguhnya "terletak pada kapasitas keterpaduan (estetika musik), yang diciptakandengan cara menyampur berbagai elemen (gaya) yang diambil dari sana-sini" Elemen-elemen itu kemudian menyatudanmenjadi bagian utuh dari aliran/gaya musikal musik yang melakukan pengasimilasian itu. Namundiingatkanbahwa hibridisasi bukan sekedarmenggandeng, meminjam, apalagi menjiplak kalimat-kalimat lagu atau mengasimilasi elemen-elemen musikal yang aneh kedalam sebuah komposisi musik.(Dziuba, 2014).

Terjadi juga dalam sebuah kelompok musik yang berada di Yogyakarta, yang memadukan musik hip-hop dengan musik tradisional. Jogja Hip Hop Foundation terdapat unsur estetis yang sangat diwarnai secara kental oleh unsur-unsur tradisi khususnya estetika dalam Kebudayaan Jawa. Hal inilah yang menjadi kekhasan estetika dalam Jogja Hip Hop Foundation. Estetika atas dasar unsur etnis musik tradisi Yogyakarta khususnya gamelan serta pertunjukan wayang kulit sangat mewarnai karya estetis yang dihasilkan JHF. Memang secara mendasar estetika JHF masih diwarnai musik hip hop yang terlahir di masa modern, sehingga estetikanyapun tidak bisa dilepaskan dari estetika modern (Laksono, Purba, \& Hapsari, 2015).

Tahun 1960-an sampai 1970-an, saat kreativitas penggabungan instrumen musik seperti mempertunjukkan piano jazz bersama dengan kecapi Sunda oleh pemusik jazz (Tjok Sinsoe, Mus Mualim dan Bubi Chen, termasuk kolaborasi dengan Tony Scott) maupun mereka yang berlatar belakang musik klasik (Idris Sardi). Pada tahun 1976 Guruh Soekarnoputra melakukan aktivitas musik hibrida menggabungkan ensambel dan teknik vokal musik tradisional Bali dengan musik rock, bersama kelompok Gypsy. Pada tahun 2000-an, ada album musik populer yang komposisi lagunya menggabungkan instrumen tradisional dan Barat. Contohnya antara lain, Ian Antono dalam kelompok musik Gong 2000 dengan gamelan Bali, Moritza Thaher bersama kelompok Nyawong dengan rapaiserta seurune kaleedan Raply Kande dari Aceh, Iwan Hasan bersama kelompok Discus dengan gamelan dan beberapa pemusik lainnya. Bahkan, program Dua 
Warna pernah menjadi program andalan di stasiun televisi RCTI, sehingga istilah "dua warna" menjadi sebutan baru untuk ragam musik yang di tahun 1970-an disebut musik eksperimen (Purba \& Pasaribu, 2008).

Hibriditas Musik menurut (Adler, 1998) adalah bagian dari konsep yang lebih besar berpusat pada seni trans-disiplin dan praktek kolaboratif. Maka musik hibrid dapat disebutkan suatu pengasimilasian elemen-elemen musikal yang formal. Dalam musik populer ada yang menggabungkan instrumen musik Barat dengan instrumen musik tradisional yang ada di Indonesia. Atau menggabungkan teknik bermain musik dan vokal dari dua ragam tradisi (etnik) atau lebih.

\section{Sistem Tangga Nada Hidrid}

Sebelum menjelaskan proses pembentukan sistem tangga nada hibrid akan mengurai mengenai deskripsi tangga nada secara umum. Tangga nada pada dasarnya merupakan komponen dari elemen musik yaitu pitch. Dari empat elemen musik yang secara umum diketahui memiliki empat unsur seperti : pitch, durasi, volume (intensitas), dan timbre (warna suara). Pitch berhubungan dengan melodi, harmoni, dan kontrapung. Durasi berhubungan dengan tempo, ritme, meter, dan beat. Volume berhubungan dengan dinamika keras lembutnya. Dan timbre berhubungan dengan warna vokal, warna instrumental, dan sumber produksi suara lainnya (Christ \& Richard, 1975).

Pitch meperupakan properti persepsi yang memungkinkan membuat urutan suara pada kaitan frekuensi tangga nada (Klapuri, 2003). Kata lebih tinggi atau lebih rendah ini menunjukkan bahwa pitch, termasuk juga tangganada, lebih dihubunngkan dengan frekuensi (jumlah getar/detik) dari pada aspek kelengkapan lainnya seperti intensitas, ataupun juga warna.Sedangkan tangga nada merupakan susunan tinggi rendahnya nada yang memiliki urutan interval dan jumlah nada tertentu, sehingga setiap kontruksi yang tersusun terdapat klasifikasi yang berbeda-beda.

Kostka (2006) menjelaskan mengenai jenis-jenis tangga nadadengan klasifikasi meliputi:

a. Five-note scales (modus lima nada)

Pentatonik adalah sebuah istilah umum untuk semua nada. Pembentukannya hanya menggunakan major second dan minor thirds. Salah satu contoh tangga nada pentatonik dibawah ini yang biasa dikatakan anhemitonic pentatonic scale (hanya berisi nada penuh) 


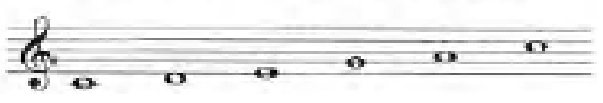

Gambar 1. The Pentatonic Scale

b. Six-note scales (modus enam nada)

Satu-satunya modus enam nada yang digunakan pada abad ke-20. Di konstruksi keseluruhan dari major 2nds.

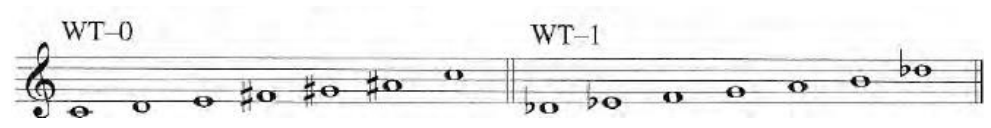

Gambar 2. Whole-Tone Scales

c. Seven-note scales (modus tujuh nada): modus diatonis

Skala modus sebagian besar telah keluar dari komposer sejak awal Barok. Tapi modalitas itu antusias ditemukan kembali oleh sejumlah komposer abad kedua puluh awal. Meskipun teori modus Renaisans diakui otentik, perbedaan ini tidak penting dalam penggunaan zaman modern.

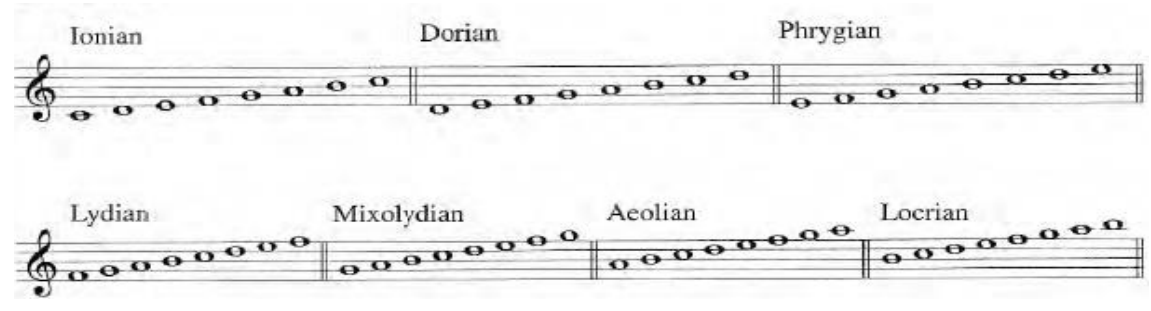

Gambar 3. The Diatonic Modes 
d. Eight-note scales (modus delapan nada)

Oktatonis sama seperti pentatonis istilah umum.

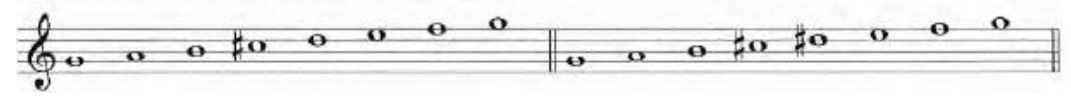

Gambar 4. Two Seven-Note Scale Systems

Adapun beberapa konsep pembentukan tangga nada yang sudah ada yaitu sebagai berikut: menurut Aristoxenus (ca. 335) pembentukan tangga nada pada awalnya sudah digunakan dari teori zaman Yunani. Dengan prinsip tetrachord, yang merupakan kelompok dari empat buah nada, dua nada yang posisinya berada di luar "tidak bergerak", dan dua nada yang posisinya di dalam "dapat bergerak" (Christensen, 2002).

Pembentukan modus juga dapat menggunakan sistem duabelas nada seperti yang terdapat pada karya Schoenberg. Esensi konsep atonal untuk menghindari rasa tonal, tonika dan tangga nada. Selain konsep bentuk modus ada juga konsep melodi (melodic pattern) sebagai penyusunan alur melodi, bahkan dapat dijadikan alat pembentuk modus. Oleh Nicolas Slonomsky merupakan komponis abad ke-20 yang mengembangkan konsep ini yang juga dapat digunakan menyusuntangga nada-tangga nada baru. Tangga nada hibrid merupakan sebuah kombinasi akor-akor dalam pendekatan dalam berimprovisasi dalam musik jazz (Dixon, 2004,Dziuba, 2014) atau disebut juga tangga nada campuran/mixture scale (Johnston, 2006, Lewis, 2007).

Dixon (2004) kemudian mengkaji komposisi musik Harry Freedman. Harry Freedmanadalah salah seorang komponis Canadian Filmyang membuat karya-karya Symphonic dan musik kamar untuk berbagai film. Beberapa bagian karyanya terdapat tangganada hibrid. Salah satu potongan notasi tangga nada hibrid dapat dilihat pada Gambar 5. Example 5-12.1: Alice in Wonderland

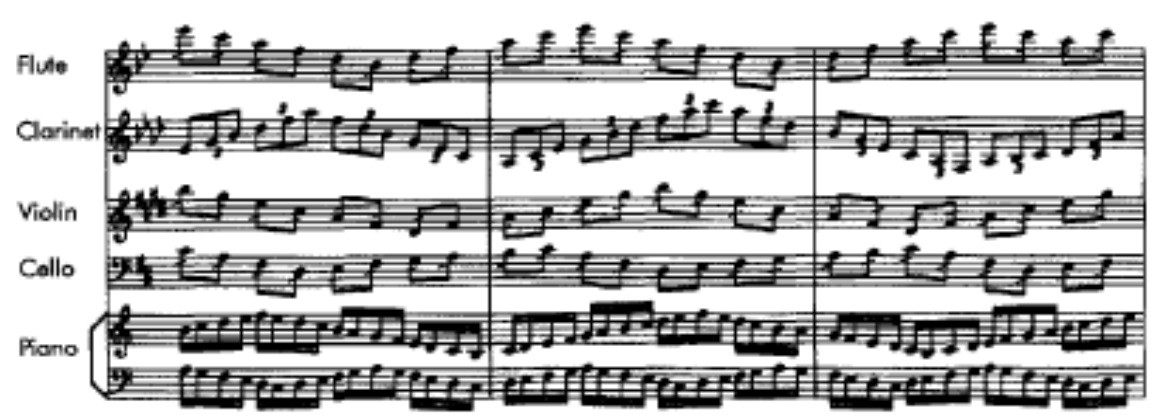

Gambar5. Potongan notasi tangga nada hibrid 
Potongan notasi di atas mempunyai key signature atau tanda kunci nada yang berbeda, dalam uraian yang dimaksudkan ketika memiliki ragam kunci tersebut secara inheren akan dapat menghasilkan skala hibrid. Pembahasan dalam bukunya merupakan lebih kepada kajian tentang aplikasi-aplikasi tangganada hibrid bukan pada sebuah konsepnya.

Lalu yang berikut adalah kombinasi tangganada dengan konsep dalam bukunya (Johnston, 2006) ada mengurai tentang bagaimana suatu tangganada campuran (mixture scale). Salah satu sistem pengembangan tangga nada dengan mencampur dari dua skala yang diturunkan. Memberikan sepuluh nada dalam satu oktaf, bisa dibagi dengan analogi dari tangga whole tone. Cara ini juga mencoba diadaptasi terkait konsep yang akan dikembangakan.

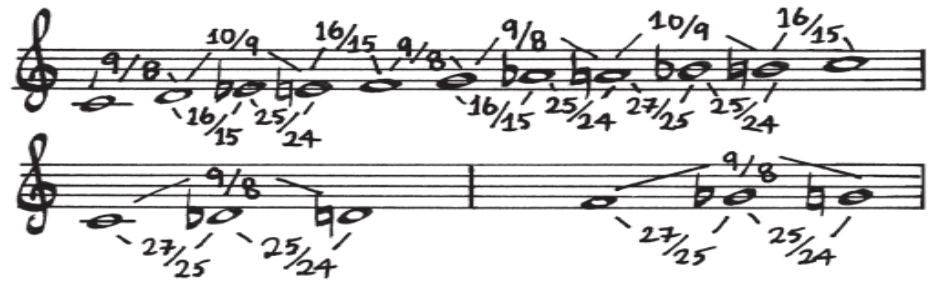

Mixture of the two scale derived in figure 13 giving ten ton to the octave. The two undivided whole tones, as shown on the lower staff, which would in combination yield a twelve-tone (chromatic scale) Gambar 6. Proses percampuran tangga nada

\section{Proses Perwujudan}

Proses perwujudan yang dilakukan melalui tiga tahapan umum dalam penciptaan, yaitu tahapan ekplorasi, eksperimentasi atau improvisasi, dan pembentukan. Dari proses yang ada tersebut secara konkret tulisan ini belum sampai pada tahap pengaplikasian tangga nada hibrid pada suatu lagu atau karya. Pada dasarnya ide penciptaan ini telah dihimpun dari berbagai sumber berupa imajinasi, kognisi baik dengan melakukan studi awal dengan meneliti bentuk-bentuk tangga yang sudah dilakukan penulis lain sebelumnya. Secara selektif merespon konsep-konsep baru sebelumnya, hal ini untuk untuk memperoleh data-data agar adanya suatu pengembangan. Maka ditentukan topik yang akan dijadikan sebagai hal-hal yang berkaitan untuk melengkapi seperti materi tangga nada yang akan di kombinasikan dan yang paling utama yaitu membuat proses atau langkah-langkah pembentukan tangganada hibrid. 
Langkah awal melakukan pengumpulan data-data seperti catatan kuliah, rekaman diskusi, yang selama berproses dalam bidang musik untuk dirangkumdan dikelompokan. Informasi untuk melengkapi konsep ini juga di peroleh dari sumber internet, seperti web, youtube, komunitas musik dalam media sosial sangat membantu melihat perkembangan terbaru saat ini. Secara teknik langkah-langka pengolahan maupun pembentukan konsep mengacu pada konsep yang telah ada sebelumnya, sehingga jelas bentuk dan kebaruan seperti apa yang di kembangkan. Referensi-referensi buku musik baik teori maupun wiyalah praktis yang ada hubungannya dengan komposisi musik menjadi penting sebagai rujukan. 
Studi pendahuluan dari beberapa buku tersebut tahapan untuk mencari dan mengetahui sistem bentuk-bentuk pengembangan tangganada.Dengan ini memilih untuk mengembangkan pada ranah tangganada dengan istilah konsep Hybrid scale (tangga nada hibrid). Dengan materi yang digunakan yaitu: tangga nadaWhole tone dan Pentatonik Batak Toba.Penulis sangat terbantu karena tersedianya referensi buku-buku tersebut dan sebagian juga diacu dari media internet sehingga memudahkan mencari informasi dan perkembangan musik saat ini di dalam dan di luar Indonesia.

Kemudian pada langkah kedua melakukan eksperimentasi sebagai penerapan ide dengan melakukan adanya kombinasi-kombinasi tangga nada. Dalam membentuk tangga nada baru dengan mengawinkan dari dua tangga menjadi satu, mencoba untuk membahas tentang bagaimana cara improvisasi dalam instrument gitar dengan kombinasi dua jenis tangganada yang berbeda menghasilkan satu skala baru. Berikut penjelasan mengenai estimasi konsep; pertama menentukan materi tangga nada yang akan dikawinkan, seperti contoh dibawah ini ada dua tangga nada yaitu A blues dan A Major pentatonis. Lalu kemudian langsung menumpukkan/menyusun nada, sehingga nada-nada belum memiliki penjelasan mengenai tonalitas dan juga langkah-langkah yang signifikan.

A blues scale

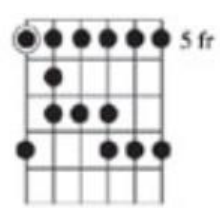

A Major pentatonic

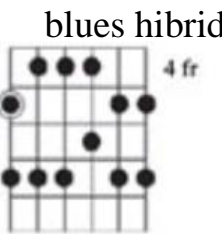

A Major pentatonic/

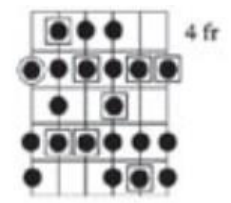

Gambar 7. Proses Penggabungan Skala Media tablature Gitar

Maka susunan melodi berikut ini yaitu hasil dari penggabungan tangganada yang telah digabungkan. Konsep ini sering digunakan untuk suatu teknik improvisasi pada sebuah lagu. Skala baru tersebut umumnya dimainkan pada teknik improvisasi seperti tangga nada konventional yang biasa digunakan.

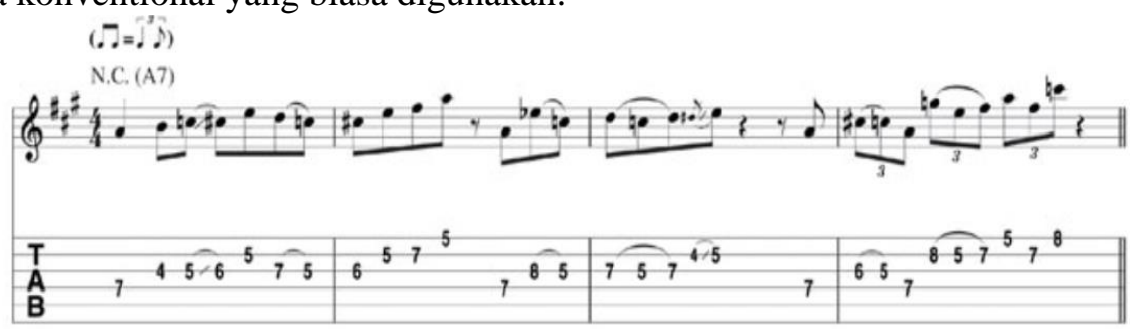

Gambar 7. Notasi Lick Hybrid Scale 
Sistem tersebut belum menjelaskantahapan pembentukannya, seperti apa interval setiap nada, klasifikasi, dan skala formula tangga nada yang akan digabungkan tidak terdapat dalam konsep ini. Aplikasi dari hasil penggabungan tangga nada tersebut sangat umum digunakan pada improvisasi intrumen gitar. Dengan mengubah materi tangga nada lain yang ingin di gabungkan, maka dapat dipakai seperti sistem di atas. Contoh notasi dengan media tablature gitar menjadi salah satu kesulitan tersendiri bagi pengguna instrument lain, maka media yang umum digunakan untuk proses pengolahan yaitu dengan tuts piano.

Pada tahapan selanjutnya untuk lebih memfokuskan pembentukan maka penentuan materi yang digunakan adalah tangga nada whole tone dan PentatonikBatak Toba.Balena (2014) mengelompokkan tangga nada berdasarkan rumus skala interval dari nada tertentu. Dalam hal ini,symmetrical scalemerupakan jarak skala setiap nada secara simetris. Skala yang terdapat pada jarak setiap nada tersusun secara teratur, contoh: 1-1-1-1-1-1, 1-2-1-21-2, 1-3-1-3-1. Golongan pentatonic scale merupakan deret interval yang terdiri dari 5 nada. Setiap skala yang memiliki 5 nada disebut sebagai pentatonic scale. Materi yang diangkat untuk melandasi rumusan karya ini yaitu whole tone dari symmetrical scale dengan skala penuh 1-1-1-1-1. Kemudian dari pentatonic scale yaitu tangga nadapentatonik batak dengan skala nada 1-1-1/2-1.

Maka rumusan estimasi pembentukannya akan dipaparkan sebagai berikut, yakni tahap pertama skala pada tangga nadawhole tonedisusun dengan huruf kunci menjadi satu unit yaitu (C-D-E-F\#-G\#-Bb). Kedua, skala pentatonik Batak Tobamenjadi satu unit yaitu (C-D-E-F-G), selanjutnya dikombinasi atau dipadukan kedua unit menjadi satu, yakni (CD-E-F-F\#-G-G\#-Bb). Susunan nada tersebut nantinya menjadi bertambah dari segi interval dan juga jumlah nada bertambah menjadi delapan.

Hasil penggabungan kedua tangga nada tersebut agar lebih meleburmaka susunan akord yang ada menjadi $\mathrm{C}$ (C-E-F\#-Bb) dan interval triad yang muncul (C-E-F\#, D-F-G, E-F\#-G\#, F-G-Bb, F\#-G\#-C, G-Bb-D).
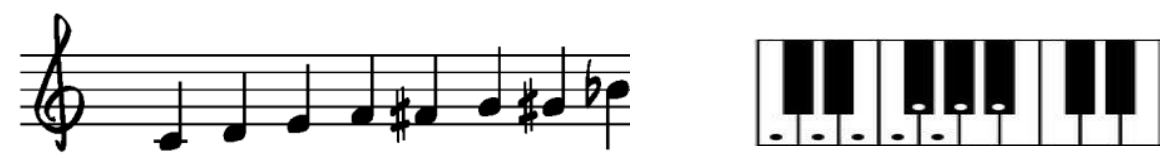

Gambar 8. Notasi Akor dari Penggabungan Skala 
Konsep ini dikembangkan berdasarkan konsep yang telah ada sebelumnnya.Adanya perbedaan sistem pembentukannyayang menguraikan langkah-langkah awal sebelum langsung kepada penggabungannya.

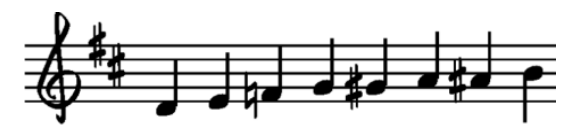

Gambar 9. Notasi Hasil Penggabungan Skala Nada

Untuk lebih melihat fungsinya, salah satu contoh tonalitas yang dipindahkan atau ditransposisi pada tonalitas yang berbeda, yang mana masing-masing interval nada tidak berpindah. Berikut contoh notasi pada Gambar 10.

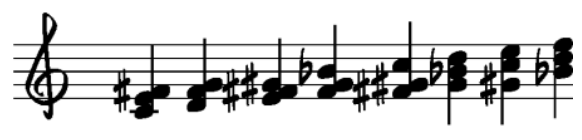

Gambar 10. Notasi transposisi

Kedua tangga nada tersebut diambil secara opsional dari dua tradisi musik. Penggunaan keduanya berdasarkan karya-karya sebelumnya yangumumnya terdapat perbedaan gaya, yakni seperti gaya impresionis dengan Gondang (musik tradisi Batak Toba). Selain penggabungan tangga nada tersebut, ada kemungkinan faktor kolaborasi tertentu seperti tekstur dari kedua unsur materi, misalnya unsur ritme, tangga nada atau melodi. Kolaborasi ini dapat diolah pada saat proses penyusunan karya, menuangkan ideide kreatif untuk memunculkan karakter yang khas. Namun untuk lebih spesifik sebagai batasan pembahasan yakni pada pengolahan tahapan yang terjadi pada penggabungan tangga nada.

Selain itu, konsep yang telah ada dapat dikembangkan sistemnya dengan menambah berbagai kemungkinan, misalnya konsep progresi akor (tonika, subdominant, dominan) dan konsep harmoni (triad, kuartal, sekundal).Sistem harmoni melandasi setiap karya,yakni dengan menggunakan dari dua aspek yang ada, seperti harmoni secara vertikal yang dikenal dengan istilah superimposing. Secara vertikal, terdapat tiga kelompok akor, yaitu mayor, minor, dan dominan 7 (Sandole, 1972). Dari penggabungan tangga nada dapat disimpulkan terdapat akord yang ada menjadi (C-E-F\#-Bb) atau konsep triad yang muncul (C-E-F\#, D-F-G, E-F\#-G\#, F-G-Bb, F\#-G\#-C, G-Bb-D). Kemudian yang kedua pembahasan harmoni secara horizontal yang lebih umum dikenal dengan istilah progresi (Russo et al., 1988). 
Kedua konsep harmoni tersebut dijadikan sebagai sistem penerapan pada wilayah praktis kompositoris. Maka hasil tangga nada hibrid tersebut sebagai langkah aplikatif untuk mengakomodir ide proses kreatif dan juga yang paling utama sebagai metode dasar membentuk kerangka/tekstur karya hingga pada hasil konkrit (tangibel).

\section{Penutup}

Hasil dari proses penciptaan ini yaitu berupa sebuah prosedur pembentukan konsep tangga nada hibrid dengan materi yang bersumber dari dua kultur musik. Ketentuan langkah-langkahteknis dalam pembentukan konsep tangga nada tersebut merupakan sebuah eksperimentasi penulis yang ditetapkan secara opsional. Hal ini juga sebagai penawaran untuk digunakan sebagai modal proses pembuatan karyapada wilayah penggunaan modus. Konsep seperti ini nantinya menjadi salah satu bagian penting untuk perkembangan pengetahuan, bertambahnya wacana khususnya dalam ranah penciptaan..

Hibriditas semacam ini akan selalu nampak dalam berbagai produk kebudayaan atas karya seni, baik dari fenomena sosial, sastra, seni, maupun kehidupan sehari-hari. Identitas kultural Indonesia yang bermacam-macam bentuk tidak pernah ditemukan bentuk aslinya, selalu berupa proses pembentukan terus menerus. Hal ini akan menjadi sebuah identitas yang hibrid dengan sistem mimikri atau sinkretisasi.

Adapun pemilihan materi tangga nada dilakukan penulis secara opsional dan relevan. Opsional dan relevan dikarenakanpenulis mempunyai identitas kultur musik (musik tradisional Batak Toba). Salah satu langkah pemikiran penulis dalam menentukan sikap dikarenakan anggapan masyarakat bahwa penulis seorang akademisi dan pelaku seni bidang musik dan hidup dalam latar belakang budaya masyarakat Batak Toba. Selain itu, tangga nada etnis lainnya juga dapat digunakan sebagai bahan penggabungan tangga nada hibrid.

Berkenaan dengan budaya yang berkembang dalam studi komposisi musik, konsep diatas bisa juga diturunkan sebagai wacana baru terkait salah satu pengembangan sistem tangga nada yang dilakukan.Perkembangan pengetahuan tidak lagi dibatasi oleh adanya koptasi yang ada dalam sebuah institusi, khususnya dalam era saat ini. Perkembangan pengetahuan juga sangat banyak berbaur, seperti adanya multidisiplin ilmu yang turut mempengaruhi perspektif terhadap melihat suatu fenomena atau gejala. Muncul ruang-ruang dan bentuk-bentuk baru yang bersumber dari gagasan berbagai macam habitus seniman. Awalnya bermula dari suatu ide sampai tahap untuk mengimplementasikan, baik dengan kaidah yang sudah ada bahkan merancangkan suatu 
kaidah/konsep baru. Paradigma-paradigma berawal dari beberapa hasil penelitian atau tulisan ilmiah kritis yang berhubungan dengan stigma tentang dominasi musik programa dalam penciptaan komposisi musik ranah akademis yang minim pembahasan intramusikal.

\section{Daftar Pustaka}

Admin. (2016). Festival Musik Tembi 2016. Retrieved from https://pamityang2an.com/festival-musik-tembi-2016

Balena, F. (2014). The Scale Omnibus. America: Saxopedia.

Bhaba, H. K. (2007). The Location of Culture.pdf. New York: Routledge.

Budiarto, T. C. (2001). Music Modern dan Ideologi Pasar. Yogyakarta: Tarawang Press.

Christ, W., \& Richard, D. (1975). Introduction to Materials and Structure of Music. New Jersey: Prentice Hall, INC.

Christensen, T. (editor). (2002). The Cambridge History of Western Music Theory. Cambridge, UK: Cambridge Universty Press.

Deliege, I., \& Wiggins, G. A. (2006). Musical Creativity: Multidisciplinary Research in Theory and Practice. Francis: Phcychology Press an Imprint of Taylor.

Dixon, G. S. (2004). The Music of Harry Freedman. Toronto: University of Toronto Press.

Dziuba, M. (2014). The Ultimate Guitar Scale Bible, 130 Scales for Improvisation. Van Nuys: Alfred Music.

Johnston, B. (2006). Maximum Clarity and Others Writing on Music. Illinois, USA: University of Illionis Press.

Koapaha, R. (2016). Disertasi : Sonare Tahunduman. Yogyakarta: Institut Seni Indonesia Yogyakarta.

Kostka, S. (2006). Materials and Techniques of Twentieth-Century Music (3rd editio). New Jersey: Prentice Hall.

Laksono, K., Purba, S. A., \& Hapsari, D. P. (2015). Musik Hip-Hop sebagai Bentuk Hybrid Culture dalam Tinjauan Estetika. Resital: Jurnal Seni Pertunjukan ISI Yogyakarta, Vol. 16 No, 75-83.

Lana, L. (2012). Allegro di Krontjong: Life and Works of Amir Pasaribu. Wesleyan University.

Lewis, R. A. (2007). Mining for Scalar Representations of Emotions in Music Database. Charlote: The University of North California. 
Mark, D. (2003). Sejarah Musik 3. Yogyakarta: Pusat Musik Liturgi.

Mark, D. (2014). Sejarah Musik 4. Yogyakarta: Pusat Musik Liturgi.

O’Donnel, K. (2011). O’Donnel. Kevin. 2011. Yogyakarta: Kasinius.

Persichetti, V. (1978). Twentieth Century Harmony. USA: Faber and Faber Limited.

Purba, M., \& Pasaribu, B. (2008). Musik Populer. Jakarta: Pendidikan Seni Nusantara.

Russo, W., Ainis, J., \& Stevenson, D. (1988). Composing Music. Chicago: The University of Chicago Press.

Sandole, A. (1972). Beginner's Method for Jazz Improvisation. Springfield, P.A: 243 Rambling Way.

Siagian, R. (2013). Penyerbukan Silang Kebudayaan Musik Nusantara. Kongres Kebudayaan Indonesia (KKI) 2013.

Sumaryo, L. E. (1978). Komponis, Pemain Musik dan Publik. Jakarta: Pustaka Jaya.

Yunita, A. T. (2012). Nasionalisme Eropa dan Pengaruh Pada Lagu Seriosa di Indonesia. Resital: Jurnal Seni Pertunjukan ISI Yogyakarta, 13(2), 159-162. 